\title{
The Role of Meaning in Life and Religious Experience amongst Young People with Specific Personality Profiles
}

\author{
Stanisław Głaz S. J. (Corresponding author) \\ Chair of Psychology, Jesuit Academy Ignatianum \\ ul. Kopernika 26, Cracow, Poland \\ E-mail: zjglaz@cyf-kr.edu.pl
}

Received: May 31, 2013 Accepted: July 15, 2013 Published: August 21, 2013

doi:10.5296/ijssr.v1i1.3790

URL: http://dx.doi.org/10.5296/ijssr.v1i1.3790

\begin{abstract}
The aims of the research I embarked on were: (a) to show the level of meaning in life, intensity of motivation to look for meaning and purpose in life, the level of personality traits and the level of religious experience: God's presence and God's absence, in the lives of young people; and (b) to show the relation between meaning in life and motivation to look for meaning and purpose in life, with religious experience: God's presence and God's absence, in groups of young people with specific personality profiles. In the research the following methods were applied: in order to define the level of religious experience: God's presence and God's absence - The Scale of Religious Experience (SRE) by S. Głaz, in order to define meaning in life - The Purpose in Life Test (PLT) by J. Crumbaugh and L. Maholick, to define intensity of motivation to look for meaning and purpose in life - The Seeking of Noetic Goals Test (SONG) by J. Crumbaugh was applied, and in order to establish the personality profiles amongst young people - The Personality Questionnaire (NEO-FFI) by R. McCrae'a and P. Costa. The research was carried out in Kraków amongst 134 university students. All of them declared that had religious experience of God's presence and of God's absence. The age of the young people ranged from 19 to 24 . The subject group comes from several non-Catholic public and Polish state universities. All students were Polish born.
\end{abstract}

Keywords: meaning in life, specific profiles of personality, students, young people, motivation, religious experience: God's presence, God's absence 


\section{Introduction}

Related literature reveals a significant connection between meaning in life, motivation to look for meaning and purpose in life, personality traits, and religious experience (Frankl, 1969; Głaz, 2011, 2013). On the one hand, religious experiences can be helpful in explaining the mystery of existence (Jung, 1982; Frankl, 1975; Krok, 2009) but, on the other hand, as claimed by Freud (1961a, 1961b) and others, it falsely assures of God's careful providence, which eventually leads to self-deception and neurotic disorders.

Religious experience often influences one's personality, which, although it may be difficult to describe, results in a noticeable change in the spiritual and psychological life. The person becomes more open to inner experience and feelings. Also, he or she becomes more creative and active (Maslow, 1964). Religious experience has therapeutic powers (Frankl, 1969). A religious person feels grateful to God (Jung, 1982; Głaz, 2000b, 2002). Since the experience affects the sphere of personality, it can be analyzed within the psychology of religion (Pargament \& Mahoney, 2005; Jaworski, 2006).

The phenomenon of religious experience is known to people of various faiths (Loewenthal, 2002), both sexes (Mercer \& Durham, 1999), and to those who are mentally healthy or ill (Peteet, 1981; Koenig \& Larson, 2001). However, related literature and studies show a visible lack of more detailed research into religious experience (Hood, Spilka, Hunsberger, \& Gorsuch, 1996; Wulff, 1997; Głaz, 2011).

Many psychologists analyze the factors that influence the occurrence of religious experiences and determine their intensity and frequency. Some scientists have shown that the emotional area has a huge influence on religious experience (Allport, 1950; Gruehn, 1960; Hine, 1969). Others, however, have shown that religious practices, such as prayer and strong faith, are the decisive factors in the frequency, intensity and efficiency of religious experience (Kuczkowski, 1993; Krok, 2009).

Religious experience, however, is a kind of human experience occurring in the context of terminal value (Vergote, 1967; Allport, 1970). It is perceived as type of genuine and immediate contact with a power recognized as divine presence (Otto, 1969). With regard to religion, it denotes a direct acquisition of knowledge about religious reality as well as of whole spectrum of human experience (Godin, 1985; Hood, Hill, \& Spilka, 2009). Research shows great deal of confusion regarding the nature of religious experience. Some researches describe this experience as profoundly religious, others show that in origin it has no religious reference. For instance, it is thought that religious experience could be a result of conflict between id and ego in the human being (Freud, 1961a); and that religious experience may be sourced by psychedelic drugs (Grof, 1985; Smith, 1964). It is also quite common to identify experiences invoked both by psychedelic substances (boundary experiences) or the brain activity stimulated by means of external tools (neurotheology) with religious experience caused by God's doing (Newberg, 2010). The reactions of people and their feelings invoked by psychedelic drugs have been illustrated by some researchers (Pahnke, 1966; Masters \& Houston, 1966; Clark, 1969). For some researchers, that kind of experience has positive consequences in the lives of some people, for others, however, experience evoked by 
psychedelic drugs has negative influence on their lives, it may lead to mental disorders and changes in behavior (Snyder, 1986; Stevens, 1987; Grof, 1995).

Meaning in life can be understood in many ways. The meaning of human life is realizd through the pursuit of excellence, this is done in community of people (Adler, 1964). Meaning in life refers to the fulfilment of available potentialities and possibilites (Maslow, 1968). Person's life task is to actualise as many of his potentialities as possible. Meaning in live is realized when human beings tended to record greater self-control, and emotional maturity (May, 1981; Rogers, 1983). According to Rogers meaning in life is associated with the process of development of the person which Rogers names "the good life". The human being is then becoming more able fully to realize potentialities, the experiences of his organism and more able to listen to himself. Meaning in life is connected with the will to live and the search for purpose in life, which in a dynamic way motivates a person to take action in order to have their needs met (Lukas, 1990). In this paper Frankl's $(1971,1992)$ definition of meaning in life was adopted. Meaning in life is based on certain assumption about the nature of the human being and its place in the universe. According to that psychologist (1987), the subject of meaning in life can be considerated two levels: one as the human needs and another as a state of meaning in life. Uniqueness and singularity are fundamental components of meaning of human life. Frankl shows that human world relates to God, who is relevant to personal lives. He believes that a human being needs to have some aim in life in order to stay mentally and spiritually healthy. Life's aim is closely related to the sense of meaning in life. Lack of the sense of meaning in life leads a human being to a feeling that life is meaningless, to a sense of emptiness and a lack of affirmation of one's own life. Crumbaugh and Maholick (1964), on the basis of Frankl's theory, created the tests - The Purpose in Life Test (PLT) and The Seeking of Noetic Goals Test (SONG) - which were used in this paper. To Polish conditions they were adapted by Popielski (1987).

In this paper the concept of relatively stable personality traits as understood by Costa and McCrae (1992) was adopted. On the basis of their theory, a test was created - The Personality Questionnaire (NEO-FFI). It was adapted to Polish conditions by Zawadzki, Strelau, Szczepaniak and Śliwińska (1998). Under the influence of new discoveries in the field of biology, psychologists noticed that the development of a human personality depends not only on the environment, culture, unconscious motivation or drives, but also on genetic factors, which, in turn, are visible in the form of certain personality traits. A trait is a significant, noticeable aspect of personality, an inborn tendency, predisposition of a human being's mental structure of biological nature. The research conducted by Costa and McCrae led to identifying five relatively stable personality traits (the Big Five personality traits). These include: conscientiousness - it is a trait which describes the degree of human perseverance and motivation in aiming for achievement; openness to experience - this trait reflects a human tendency to seek new experiences and positively assess life experiences, as well as their curiosity about novelty and cognitive curiosity; agreeableness - it is a trait that describes attitude towards other people and to the environment; extraversion - depicts the ability for social interactions and the quality thereof; neuroticism - describes the vulnerability to experience negative emotions and sensitivity to psychological stress. 
Being interested in the issue of the role of meaning in life, motivation to look for meaning and purpose in life, and religious experience: God's presence and God's absence, within various groups, the author has attempted to show the relation between the aforementioned variables in the lives of young people in the present period of clearly noticeable socio-cultural change in Poland.

It must be explained that in the present work the author is interested in religious experience which has a theistic orientation referring to the Christian religion, not to the world view (Judaism, Islam) or the naturalistic, atheistic type. The core assumptions of theism on religious experience referring to the Christian religion is: belief in God. A human being can communicate with God through prayer and other spiritual practices. The spirit or soul is of divine creation, and constitutes the lasting or eternal identity of the human being (Frankl, 1987; Głaz, 1998; Richards \& Bergin, 2004; Popielski, 2008).

The author of this paper, on the basis of the concept of religious experience in accordance with the Christian religion (Rahner, 1984; Głaz, 1998), created a study tool for measuring the intensity of God's absence and God's presence (Scale of Religious Experience) (Głaz, 2011). The following elements should be distinguished in it: the subject of religion (a human being with their cognitive, emotional and volitive spheres), the object of religion (God personified) and religious relation, which is personal in character. The latter can be defined as a kind of bond with God personified through which a human being attains the aims of his or her own existence. In the process of religious experience we have shown three stages: the openness of a human being to God, communication of God with a human being, and acceptance by the human being of the influence of God's spirit that inspires, comforts, heals and lives in harmony with themselves and the universe. Religious experience finds realization during a religious act (Jarosz, 2003). A religious act is set in a human being's spiritual self. What is a religious act? It is a special action of a human being (soul and self) directed at God personified. A human being, when entering a relation with God, gains new knowledge about other person and herself or himself. Through that knowledge God 'speaks' to them and a human being responds with their faith, love and involvement (Zdybicka, 1979). What decides about the type of religious experience are elements brought in by both man and God, taking into consideration the uniqueness and distinctive features of those elements. That is why a human being shows two different kinds of religious experience in their life: experience of God's absence and of God's presence. These sorts of experience are specific and unique. They are frequently a source of different and new knowledge, which can be subject to psychological analysis. They are also a reason why opposing feelings appear in human life, like happiness - sadness, elation - doubt. The intensity of those feelings, which are set in a human personality, is volatile, and their consequences are visible in a human being's attitude (Głaz, 2011).

\section{Research Aims and Hypotheses}

Use the Scale of Religious Experience ( $S R E$ ) amongst numerous groups of people carrying out important empirical material. This shows that young people with a high level of experience of God's presence revealed greater religious commitment, greater involvement in 
pursuit of goals than young people with a low level of same (Głaz, 2002). A high level of a sense of meaning in life is revealed by women studying forestry who have a low level of the experience of God's presence (Głaz, 2003). Other studies show that young women studying philosophy show a higher level of God's presence than women students of vocational schools (Głaz, 2004). The fascination with God is strong associated with experience of God's presence in their lives by young people Głaz, 2003). The emotional sphere is strongly related to religious experience of God's presence in their lives by students (Głaz, 1996). The intensity of religious experience correlates strongly with happiness, frequency of religious practice, personal realationships (Drożdż, 2003; Soiński, 2006). The students with a high level of openness to experience show a greater sense of the divine. Their belief is more flexible, also reveals more curiosity in searching for new experience than students with a low level. They show better relations with their friends and families, a greater feeling of personal security, and they also seem to be associated with greater social involvement (Krok, 2009). In addition, another study (Szymołon, 1999) shows that the experience of a son's fear of God is vitally and positively correlated with the experience of being close to the world and to other people and to self-trust.

A question appears: who to include as subjects of the study? In times of searching for new solutions both in private and in social life, in the period of young people's changing one set of values for another, and the phase of one's own religious change in Poland (Dróżdż, 2003; Jaworski, 2006; Popielski, 2008; Soiński, 2010) it is advisable to conduct a study amongst young university students of various faculties. What is typical for early adulthood is that a young person, after turbulent developmental changes leading to biological and social adulthood, is aware of his or her ability to procreate, responsibility to take on new social roles, professional work and autonomy to direct their own life.

The research was carried out among 152 students, who were tested in order to produce empirical data which could be used to find the answers to the questions that had been raised. Four groups of people between the ages of 19 and 24 were taken into account: female pedagogy students, female forestry students, male philosophy students and male theology students. 134 properly filled questionnaires were taken into account during the analysis. All questioned persons declared themselves as religious and all of them had religious experience of the ontological nature.

The study problem of this paper suggests finding a relation between the following life factors:

- regarding meaning in life;

- concerning motivation to look for meaning and purpose in life;

- regarding personality traits with religious experience: God's presence (OB) and God's absence (NB) in a groups of young people.

The research problem suggests the following hypotheses:

H1. A sense of meaning in life is more strongly related to experience of God's presence in the group of young people with personalities of social nature than immature, 
whereas attainment of goals is more strongly related to experience of God's absence in the group of young people with personalities of humanists rather than neurotics.

H2. Motivation to look for meaning of life is more strongly related to experience of God's presence in the group of young people with personalities of social nature rather than immature, whereas a need for action is more strongly related to experience of God's absence in the group of young people with personalities of humanists than neurotics.

\subsection{Characteristics of the Research Methods and Subjects}

In this paper the following methods available in psychology were used:

a) In order to estimate the intensity of the religious experience - God's presence and God's absence, the author of the paper prepared his own Scale of Religious Experience (SRE). There are three sub-scales in this scale. The first one estimates the general religious experience of God (DB). The second sub-scale refers to the intensity of experience of God's presence (OB). The last sub-scale is used for the estimation of God's absence experience results (NB). Factor validity were applied. For the interpretation of the results of factor analysis, the variables (statements) whose loadings exceeded 0.400 were taken into account. The scale has three sub-scales. The first one describes the intensity of the experience of God in general (DB); Cronbach's alpha coefficient of internal consistency is 0.92 . The second scale serves to measure the intensity of the experience of God's presence (OB), with Cronbach's alpha coefficient of internal consistency at 0.94 . The third scale describes the intensity of the experience of God's absence (NB). Cronbach's alpha coefficient of internal consistency is also high and stands at 0.91 (Głaz, 2011, 2013).

b) The Seeking of Noetic Goals Test (SONG) - J. Crumbaugh was applied to estimate the intensity of motivation to look for meaning and purpose in life. The first factor determines the intensity of motivation to look for the meaning of life (MS), the second factor determines the intensity of motivation to look for life purposes (MC), and the third factor indicates the need for action (MF) (Popielski, 1987).

c) In order to define the degree of intensity of the experience of meaning in life among students, the Purpose in Life Test (PLT) - J. Crumbaugh and L. Maholicka was used. The following classification of statements was applied in this paper. These are: a sense of meaning in life (SZ); attainment of life goals (CZ) and affirmation of life (DZ) (Popielski, 1987).

d) The Personality Questionnaire (NEO-FFI) - R. McCrae'a and P. Costa was applied to describe five personality factors. This questionnaire was used to describe five personality dimensions: neuroticism (NEU), extraversion (EKS), openness to experience (OTW), conciliatory attitude (UGD) and conscientiousness (SUM). The NEO-FFI is essentially an empirically - based taxonomy of personality traits that has been derived from research on the everyday language terms that people use to describe themselves (Costa \& McCrae, 1992; Zawadzki, Strelau, Sczczepaniak, \& Śliwińska, 1998). 


\section{Characteristic of the Research Results}

The psychological quantitative analysis was applied to the results obtained from all the groups. Average values (M), standard deviations (SD) and variance analysis were taken into account. The results of four groups obtained from the 5-factor Personality Questionnaire (NEO-FFI), The Seeking of Noetic Golas Test (SONG), The Purpose in Life Test (PLT) and The Scale of Religious Experience (SRE) will be therefore discussed. The statistically significant differences or similarities between the groups of tested students in the range of average profiles will make it possible to find the answers to the questions that had been raised. Also the analysis of multiple stepwise regression was used. This type of method defines the relationship between an independent variable and a dependent variable, and it establishes the percentage value of the explained variance of the dependent variable $\left(\mathrm{R}^{2}\right)$.

A) Relation of the university major and the sex with the dependent variables

The presented results show several differences that are statistically significant in the test of SRE in OB and NB factors. Women who study pedagogy are more aware of the experience of God's presence $(\mathrm{OB})$ than philosophy students $(\mathrm{p}<0.05)$, whereas philosophy students seem to be more aware of the experience of God's absence (NB) than the female students of pedagogy $(\mathrm{p}<$ $0.05)$. In the questionnaire concerning the personality dimensions (NEO-FFI), as for the factor describing neurotic conditions (NEU), the female students of forestry show a higher level of neuroticism (NEU) than male students of philosophy and theology $(\mathrm{p}<0.04)$. The analysis of the results obtained from the $S O N G$ test show the lack of significant statistical differences. Some differentiation tendencies can only be seen between particular groups of students as far as motivation to find the meaning and purpose of life is concerned. The highest motivation to look for the purpose of life and achieve it is found among female students of pedagogy, while female students of forestry are the most aware of their purpose of life. The lowest results in this area are shown among male philosophy students. The results obtained in the PLT show that some differentiation tendencies among particular groups of students exist only within the scope of purpose of life examination. It means that, as far as the purpose of life is concerned, the highest rate is found among female pedagogy students and, as far as the awareness of life purposes is concerned, the highest rate is found among the students of theology. The lowest awareness of life purposes can be found among philosophy students.

B) Relation of meaning in life with God's presence and God's absence in the lives of young people with varied personality profiles

Sex and the type of education influenced only a few personality characteristics included in the research. It has been assumed that the remaining characteristics may be determined by mental values other than sex or a type of education. In order to determine particular personality profiles amongst young university students and to show the relation of meaning in life and motivation to look for meaning and purpose in life with religious experience: God's presence and God's absence, in the particular groups of young people with specific personality_profiles, the values obtained in the Personality Questionnaire (NEO-FFI), as criteria variables, were analysed by means of Cluster Analysis and Variance Analysis. As a result of extensive research carried out on the above described sample of students, a division into groups of people of similar 
personality traits was carried out.

The group of young people who were tested is not homogeneous. The values obtained in the Personality Questionnaire (NEO-FFI) were studied according to the cluster analysis, as a result of which four groups of young people (four clusters) of various profiles were discerned (Table $1)$.

Table 1. Variance Analysis (ANOVA) (F, p) for all cluster analysis obtained for four groups of young people

\begin{tabular}{|c|c|c|c|c|c|c|c|c|c|c|c|}
\hline \multirow[t]{2}{*}{ Variables } & \multicolumn{2}{|c|}{ Cluster I } & \multicolumn{2}{|c|}{ Cluster II } & \multicolumn{2}{|c|}{ Cluster III } & \multicolumn{2}{|c|}{ Cluster IV } & \multirow[t]{2}{*}{$\mathrm{F}$} & \multirow[t]{2}{*}{ df } & \multirow[t]{2}{*}{$\mathrm{p}$} \\
\hline & M & SD & M & SD & M & SD & M & SD & & & \\
\hline SUM & 7.7 & 2.18 & 8.1 & 2.31 & 6.1 & 2.59 & 6.2 & 2.85 & 47.93 & 3 & 0.0001 \\
\hline UGD & 7.3 & 1.89 & 6.7 & 1.45 & 7.1 & 3.19 & 6.3 & 1.99 & 18.25 & 3 & 0.0001 \\
\hline OTW & 6.6 & 2.19 & 6.5 & 3.12 & 6.3 & 2.42 & 6.1 & 2.49 & 3.25 & 3 & 0.05 \\
\hline EKS & 7.2 & 2.45 & 7.5 & 2.12 & 6.2 & 2.21 & 6.4 & 2.73 & 32.24 & 3 & 0.0001 \\
\hline NEU & 6.6 & 1.99 & 4.5 & 1.88 & 4.5 & 1.32 & 5.1 & 2.78 & 36.76 & 3 & 0.0001 \\
\hline
\end{tabular}

The first cluster - the smallest one - consists of 25 young people; the second - the biggest one consists of 41 people. There are 30 young people in the third cluster and 38 young people in the fourth cluster. Each group contains young people of similar personalities. The first group includes young people who are interested in others and try to give support to others (of social nature). The second group of young students includes people who are sensitive to others (the humanists) and have a well-built structure of their own self. These young people are very conscientious and agreeable. The third group includes young people whose personality is immature (the immature), as a result of which they do not really care about others. The last group consists of young people whose level of neuroticism is higher (the neurotics). Such people are not very confident as for their own development. Their personality, their commitment is often accompanied by anxiety.

a) It was also an objective to show the relation of meaning in life with experience of God's presence (OB) and God's absence (NB) in the lives of groups of young people with specific personality profiles. It was assumed that the variables obtained in the PLT were independent variables, and the values obtained in the $S R E$ test were dependent variables (Table 2). 
Table 2. Independent variables concerning meaning in life: a sense of meaning in life (SZ), and attainment of life goals (CZ) explaining the variance God's presence (OB) and attainment of life goals (CZ) explaining the variance God's absence (NB) in the groups of young people with specific personality profiles

\begin{tabular}{|c|c|c|c|c|}
\hline Groups & $\begin{array}{l}\text { Independent variables explaining } \\
\text { the OB variance }\end{array}$ & $\mathrm{R}$ & $B$ & $\begin{array}{l}\text { Per cent of explained } \\
\text { variance }\left(\mathrm{R}^{2} \times 100 \%\right)\end{array}$ \\
\hline \multirow{4}{*}{$\begin{array}{c}\text { Social } \\
\text { nature } \\
\text { Humanists } \\
\text { Immature }\end{array}$} & $\mathrm{SZ}$ & 0.6105 & 0.23 & 37 \\
\hline & $\mathrm{CZ}$ & 0.4547 & 0.19 & 21 \\
\hline & $\mathrm{SZ}$ & 0.5104 & 0.26 & 26 \\
\hline & $\begin{array}{c}\text { Independent variable explaining } \\
\text { the NB variance }\end{array}$ & $\mathrm{R}$ & & $\begin{array}{l}\text { Per cent of explained } \\
\text { variance }\left(\mathrm{R}^{2} \times 100 \%\right)\end{array}$ \\
\hline $\begin{array}{l}\text { Social } \\
\text { nature }\end{array}$ & $\mathrm{CZ}$ & 0.3821 & 0.23 & 14 \\
\hline
\end{tabular}

Two different independent variables related to looking for meaning in life explain the variance of the OB dependent variable in particular groups. In the group of young people of social nature the variable referring to a sense of meaning in life (SZ) is the most noticeable. The variable explains $37 \%$ of the variance of the $\mathrm{OB}$ dependent variable $(\mathrm{R}=0.6105)$. The correctness of the stepwise regression equation that has been formulated determines the value of the test: $\mathrm{F}=16.67, \mathrm{df}=1 ; \mathrm{p}<0.05$, and the multiple regression equation is as follows: $\mathrm{OB}$ $=12.71+23 \times \mathrm{SZ}$. In the group of humanists the variable related to the attainment of life goals (CZ) is the most significant. It explains $21 \%$ of the variance of the OB dependent variable $(\mathrm{R}=0.4547)$. The correctness of the stepwise regression equation that has been formulated determines the value of the test: $\mathrm{F}=10.16$, $\mathrm{df}=1 ; \mathrm{p}<0.05$. The regression equation is as follows: $\mathrm{OB}=47.15+0.19 \mathrm{x} \mathrm{CZ}$. In the group of the immature the variable concerning the a sense of meaning in life (SZ) appears. The variable explains $26 \%$ of the variance of the $\mathrm{OB}$ dependent variable $(\mathrm{R}=0.5104)$. The correctness of the stepwise regression equation that has been formulated determines the value of the test: $F=9.86, \mathrm{df}=1$; $\mathrm{p}<0.05$, and the regression equation is as follows: $\mathrm{OB}=44.05+0.26 \times \mathrm{SZ}$

Only one independent variable referring to looking for meaning and purpose in life influences the NB dependent variable. Such phenomenon occurs within the group of young people of social nature and refers to attainment of life goals (CZ). It explains $14 \%$ of the variance of the NB dependent variable $(\mathrm{R}=0.3821)$. The correctness of the stepwise regression equation that has been formulated determines the value of the test $\mathrm{F}=5.40$, df $=1 ; \mathrm{p}<0.05$, and the multiple regression equation is as follows: $\mathrm{NB}=-12.16+0.23 \times \mathrm{CZ}$.

b) It was also resolved to study the relation of motivation to look for meaning and purpose in life with the experience of God's presence (OB) and God's absence (NB) in the groups of young people with specific profiles of personality. It was assumed that the variables obtained in the $S O N G$ test were independent variables, and the values obtained in the $S R E$ 
test were dependent variables (Table 3).

Table 3. Independent variables concerning the motivation to look for meaning and purpose in life: the need for action (MF) explaining the variance God's presence (OB) and the motivation to look for life purposes (MC) explaining the variance God's absence (NB) in the groups of young people with specific profiles of personality

\begin{tabular}{ccccc}
\hline Groups & $\begin{array}{c}\text { Independent variable explaining } \\
\text { the OB variance }\end{array}$ & $\mathrm{R}$ & $\mathrm{B}$ & $\begin{array}{c}\text { Per cent of explained } \\
\text { variance }\left(\mathrm{R}^{2} \times 100 \%\right)\end{array}$ \\
\hline Neurotics & $\mathrm{MF}$ & 0.7011 & 0.22 & 49 \\
\hline & $\begin{array}{c}\text { Independent variable explaining } \\
\text { the NB variance }\end{array}$ & $\mathrm{R}$ & & $\begin{array}{c}\text { Per cent of explained } \\
\text { variance }\left(\mathrm{R}^{2} \times 100 \%\right)\end{array}$ \\
\hline $\begin{array}{l}\text { Social } \\
\text { nature }\end{array}$ & $\mathrm{MC}$ & 0.4359 & 0.18 & 18 \\
\hline
\end{tabular}

One independent variable related to the motivation to find the meaning in life explains the variance of the OB dependent variable in one of the group of young people. In the group of neurotics the variable referring to the need for action (MF) is the most noticeable. The variable explains $49 \%$ of the variance of the $\mathrm{OB}$ dependent variable $(\mathrm{R}=0.7011)$. The correctness of the step regression equation that has been formulated determines the value of the test: $\mathrm{F}=34.81, \mathrm{df}=1 ; \mathrm{p}<0.05$, and the multiple regression equation is as follows: $\mathrm{OB}=$ $37.99+0.22 \times \mathrm{MF}$.

Only one independent variable related to the motivation to find meaning in life influences the NB dependent variable. Such a phenomenon occurs within the group of young people of social nature and refers to the motivation to look for life purposes (MC). It explains $18 \%$ of the variance of the NB dependent variable $(\mathrm{R}=0.4359)$. The correctness of the step regression equation that has been formulated determines the value of the test: $F=5.40, \mathrm{df}=1$; $\mathrm{p}<0.05$, and the multiple regression equation is as follows: $\mathrm{NB}=-11.16+0.18 \times \mathrm{MC}$.

\section{Discussion}

The analysis of the research problem concerning the relationship between meaning of life, motivation to find meaning in life, and experience of God's presence and God's absence shows that there exists a significant connection between those dimensions in lives of students of different faculties and personality profiles. Each of them dimensions is considered in this analysis plays an important role in the development of young people.

a) The analysis of the results obtained from the research carried out among male and female young students of different university majors show that sex and type of studies significantly differentiate only some elements from amongst such dimensions of human life as religious experience, meaning in life, motivation to find meaning in life, and personality traits. It is worth noting that the level of the awareness of experiencing God's absence was the highest among male students, and the lowest among female students. Also, men - in particular philosophy students reveal the highest level of the awareness of experiencing God's presence and God's absence 
among all the tested groups. This is in contrast with the results obtained by Pafford (1973) whose research proved that women are more prone to religious experience and more women, as compared to men, have experienced such kind of phenomena. Other research, carried out by Marcer and Durham (1999) proves that it is not sex that determines the level of intensity of religious experience, but the openness to such experience. The results obtained from the subgroup of theologians are very surprising. It was expected that the intensity of religious experience among theology students would be very high, but the results showed that it is not true. The conclusion is that studying theology, or the theological knowledge of a person does not actually influence the student's intensity of religious experience. Therefore, contrary to the results obtained by some scholars (Poloma \& Gallup, 1991), it seems that is not knowledge that develops religious experience, but contemplative prayer or religious upbringing (Saroglou, 2001).

Only in case of one factor related to personality traits, i.e. neuroticism, a statistically significant difference is noticeable. Women reveal a higher level of neuroticism than men. It is suggested that women are more sensitive and thus more prone to experiencing deeper emotions. Conflict situations that occur in their lives may have a worse influence on their mental state than on the psyche of men (Głaz, Grzeszczek, \& Wiśniewska, 1996). As for meaning in life, only a few differentiating tendencies are noticeable among the young students of both sexes and young students studying at different universities. Men reveal a higher sense of meaning in life than women, and their life purposes are more specific than the life purposes of their female counterparts. Men are more motivated to find and fulfil the meaning of life and to fulfil their life purposes. This time the tests have not confirmed the previous results of the author's research (Głaz, 2003) according to which women's sense of meaning in life was higher than men's. Comparing young people from particular universities in this regard, it is worth noting that female pedagogy students reveal the highest level of the sense of meaning in life and the highest level of the motivation to find meaning and purpose in life, while male theology students are the most aware of their life purposes.

b) The first hypothesis, which indicates a significant contribution of a sense of meaning in life to explaining the variance of experience of God's presence in a group of young people with personalities of social nature and of the immature as well as a significant contribution to attainment of goals to explaining the variance of experience of God's absence in the group of young people with personalities of humanists and neurotics, was only partly confirmed. According to the first part of the hypothesis, in relation to the theories of Frankl (1975) and Popielski (1987), a sense of meaning in life contributes to a larger extent to explaining the variance of experience of God's presence in the group of young people with personalities of social nature than in the group of the immature. The second part of the hypothesis, however, which indicates a stronger contribution of attainment of goals to explaining the variance of experience of God's absence in the group of young people with personalities of humanists than in the group of neurotics, was not fully confirmed. None of the variables relating to meaning in life shows a significant relationship with the experience of God's absence both in the group of humanists and neurotics. It was expected, in accordance with some researchers' conclusions (Jaworski, 2006; Krok, 2009) that in the group of young people with personalities of humanists attainment of goals is significantly related to experience of God's absence. 
c) The second hypothesis, which indicates a significant contribution of motivation to look for meaning in life to explaining the variance of experience of God's presence in the group of young people with personalities of social nature and the immature, as well as a significant contribution of need for action to explaining the variance of experience of God's absence in the group of young people with personalities of humanists and neurotics, was not fully confirmed. It was expected, in accordance with the researchers' theory (Frankl, Popielski), and which was also confirmed in this study, that if a sense of meaning in life contributes to a greater extent to explaining the variance of experience of God's presence in the group of young people with personalities of humanists than in the group of the immature, then the variable relating to motivation to look for meaning in life ought to show a stronger contribution to explaining the variance of God's presence in the group of students with personalities of social nature than the immature. In this case, motivation to look for meaning in life has no significant relation with experience of God's presence, and a need for action shows no significant relation with experience of God's absence both in the group of young people with personalities of humanists and of neurotics.

d) The analysis of the present study indicates that amongst variables relating to meaning in life, a sense of meaning in life is the strongest predictor of experience of God's presence and it refers to the group young people of social nature and the immature. It is worth pointing out that life's affirmation shows no significant relation to experience of God's presence in any of the groups of young people with various personality types. The only variable that has a significant relation with experience of God's absence seems to be attainment of goals and this in the group of young people with a personality of social nature. The two remaining variables (a sense of meaning in life and affirmation of life) show no significant relation to experience of God's absence in either of the groups of young people with different personality types.

When it comes to the relation of motivation to look for meaning and purpose in life with the experience of God's presence and God's absence in particular groups of young people with various personality profiles, the situation looks different. Namely, the only really strong variable explaining the variance of experience of God's presence (49\%), which was by no means expected, turned out to be the variable 'need for action' and this only in the group of neurotics. Similarly, only one variable - motivation to look for purpose in life - has a significant relation with the experience of God's absence - it explains $18 \%$ of the variance of that experience, and it refers only to the group of young people of social nature. It must be stressed that, in accordance with the theory of some researchers and related studies, a greater contribution of variables relating to motivation to look for meaning and purpose in life to explaining the variance of experience of God's presence and God's absence in particular groups of young people with varied personality profiles was expected.

The strongest contribution of meaning in life as well as motivation to look for meaning and purpose in life to explaining the variance of experience of God's presence and God's absence can be observed in the group of young people with a personality profile of social nature. Furthermore, the weakest contribution of the aforementioned variables to explaining the variance of religious experience - and it refers to God's presence - was recorded in the group of young people with personalities of humanists. 
It was expected that more variables concerning meaning in life as well as motivation to look for meaning and purpose in life would be connected with the students' religious experience related to God's presence and God's absence. This research does not fully confirm the research carried out by other scientists who showed that the aforementioned variables are connected with religious experience and strongly influence such experience (Frank1, 1975; Glaz, 2011). It seems that students are more interested in improving their knowledge than fulfilling their own existential references and needs.

Theoretical works, inner personal experience and analysis of the empiric data reveal that religious persons, regardless of their age, gender, level of education and social environment, may face the existential experience of religious character defined as God's presence or God's absence. Experience of this kind has its own specific structure and its own way of progress (Głaz, 2000a). Such transitory phenomena are often difficult to describe. The God's presence experience usually occurred during prayers. It used to appear suddenly and was accepted with enjoyment. One's longing for God and developed religious attitude facilitated such experience. However, the experience itself can radically influence various aspects of one's personality. As for the experience of God's absence, it was usually received as a state of being abandoned by God and occurred at the time of an existential crisis. Such kinds of experience, appearing suddenly like the others, were followed by a feeling of disappointment and accompanied by anxiety. Solitude and prayer were favourable factors for such kinds of experience (Głaz, 1998). The experience of God's presence and God's absence usually influences one's future attitude and behaviour.

It must be emphasized that a method of researching the contemporary people's religious experience, which was used in this paper, focusing on the experience of God's presence and God's absence, is a new research idea in the area of the psychology of religion.

Variables related to meaning in life as well as motivation to look for meaning and purpose in life, which were taken into account in the research, influence - to a greater or lesser degree - the variability of experiencing God's presence and God's absence, but they do not fully explain such variability. There is no doubt that there are a lot more psychological variables that could explain the variability of religious experience if they had been taken into account in the present analysis of the problem.

The research performed has not definitely solved problems related to the God's presence and God's absence religious experience that may be known to the young students. Another series of empirical research, using tools available in psychology and taking into account some other dimensions of the contemporary man's personality, should be performed in future. Similar conclusions could result from the research oriented towards the opposite direction, which would show an influence of the God's presence and God's absence religious experience on various dimensions of the contemporary man's personality.

\section{References}

Adler, A. (1964). Understanding Human Nature. New York: Greenberg Publisher.

Allport, G. (1950). The Individual and His Religion: A Psychological Interpretation. New York: Macmillan. 
Allport, G. (1970). Structure et développement de la personnalité. Neuchatel: Delachaux Niestle.

Clark, W. (1969). Chemical Ecstasy. Psychedelic Drugs and Religion. New York: Scheed and Ward.

Costa, P., \& McCrae, R. (1992). Four Ways Five Factors are Basic. Personality and Individual Differences, 6, 653-665. http://dx.doi.org/10.1016/0191-8869(92)90236-I

Crumbaugh, J., \& Maholick, L. (1964). An Experimental Study in Existentialism. The Psychometric Approach to Frankls Concept Noogenic Neurosis. Jornal of Clinical Psychology, $20, \quad 198-229$. http://dx.doi.org/10.1002/1097-4679(196404)20:2<200::AID-JCLP2270200203>3.0.CO;2-U

Drożdż, M. (2003). Współczesne wyzwania duszpasterskie. In Naśladować Chrystusa (Les défis contemporains dans le travail du pretre) danse (Imiter le Christ) (pp. 11-28). Katowice: Księgarnia św. Jacka.

Frankl, V. (1969). The Will to Meaning. New York: New American Library.

Frankl, V. (1971). Homo patiens. Warszawa: PAX.

Frankl, V. (1975). The Unconscious God: Psychotherapy and Theology. New York: Simon \& Schuster.

Frankl, V. (1987). La sofferenza di una vita senza senso. Torino: Boringhieri.

Frankl, V. (1992). Der Wille zum Sinn. Bern: Hans Huber.

Freud, S. (1961a). The Future of an Illusion. In Standard Edition, vol. 21, pp. 1-56. London: Hogarth Press and the Institute of Psycho-Analysis.

Freud, S. (1961b). A Religious Experience. In Standard Edition, vol. 21, pp. 167-172. London: Hogarth Press and the Institute of Psycho-Analysis.

Głaz, S. (1996). Intensywność doświadczenia religijnego a koncepcja siebie (The Intensity of Religious Experience and Self-Concept). Kraków: WAM.

Głaz, S. (1998). Doświadczenie religijne (Religious Experience). Kraków: WAM.

Głaz, S. (2000a). Doświadczenie religijne a osobowość (Religious Experience and Personality). Kraków: WAM.

Głaz, S. (2000b). An Individual and Religious Experience. Cracow: WAM.

Głaz, S. (2002). Doświadczenie religijne a sens życia (Religious Experience and the Meaning of life). Kraków: WAM.

Głaz, S. (2003). Wpływ zmiennych egzystencjalnych na skutki przeżycia religijnego (Effect of Existential Variables to the Effects of Religious Experience). Czasopismo Psychologiczne, 1, 119-132. 
Głaz, S. (2004). Wybrane determinanty przeżyć religijnych (Selected determinants of religious experiences). Roczniki Psychologiczne KUL, 1, 77-99.

Głaz, S. (2011). Osobowościowe uwarunkowania przeżycia religijnego młodzieży studiującej (Psychological factors of religious experience in young university students). Kraków: WAM.

Głaz, S. (2013). The Role of the Meaning of Life and Religious Experience of God's Presence and God's Absence Among Students with Different Levels of Conscience Sensitivity. Religions, 4. http://dx.doi.org/10.3390/re14010132

Głaz, S., Grzeszek, K., \& Wiśniewska, I. (1996). Rodzina. Biologiczne i psychologiczne podstawy jej funkcjonowania (Family. Biological and Psychological Basis of its Functioning). Kraków: Wydział Filozoficzny TJ.

Godin, A. (1985). The Psychological Dynamics of Religious Experience. Birmingham: Religious Education Press.

Grof, S. (1985). Beyond the Brain: Birth, Death, and Transcendence in Psychotherapy. Albany: State University of New York Press.

Grof. S. (1995). Realms of the human unconscious, observations from LSD research. London: Souvenir Press.

Gruehn, W. (1960). Die Frommigkeit der Gegenwart: Grundtatsachen der empirischen Psychologie. Konstanz: Friedrich Bahn Verlag.

Hine, W. (1969). Pantecostal Glossolalia: Toward a Functional Interpretation. Journal for the Scientific Study of Religion, 8, 211-266. http://dx.doi.org/10.2307/1384335

Hood, R., Hill, P., \& Spilka, B. (2009). The psychology of religion: An empirical approach. New York and London: Guilford Press.

Hood, R., Spilka, B., Hunsberger, B., \& Gorsuch, R. (1996). The Psychology of Religion. An Empirical Approach. New York - London: The Guilford Press.

Jarosz, M. (2003). Interpersonalne uwarunkowania religijności (Interpersonal Considerations of Religion). Lublin: TN KUL.

Jaworski, R. (2006). Harmonia i konflikty (Harmony and Conflict). Warszawa: WKSW.

Jung, C. (1982). Esperienza e mistero. Torino: Paulo Boringhieri.

Koenig, H., \& Larson, D. (2001). Religion and Mental Health: Evidence for an Association. International Review of Psychiatry, 13, 67-78. http://dx.doi.org/10.1080/09540260124661

Krok, D. (2009). Structural Relations between Religiosity and Spirituality in the Context of Personality Factors. In H. Gasiul, \& E. Wrocławska-Warchala (eds.). Personality and Religion (pp. 280-299). Warsaw: UKSW.

Kuczkowski, S. (1993). Psychologia religii (Religious Experience). Kraków: WAM.

Loewenthal, K. (2002). Are Women More Religious then Men? Gender Differences in Religious 
Activity Among Different Religious Groups in the UK. Personality and Individual Differences, 32, 133-140. http://dx.doi.org/10.1016/S0191-8869(01)00011-3

Lukas, E. (1990). Geist und Sinn. Logotherapie - die dritte Wiener Schule der Psychotherapie. Monachium: Psychologie Verlags Union.

Maslow, A. (1964). Religions, Values, and Peak-Experiences. Columbus: Ohio State Univesity Press.

Maslow, A. (1968). Toward a Psychology of Being. New York: Van Nonstrand Reinhold.

Master, R., \& Houston, J. (1966). The Varietes of Psychodelic Experiences. New York: Delta.

May, R. (1981). Freedom and Destiny. Now York: Norton.

Mercer, C., Durham, Th. (1999). Religious Mysticism and Tender Orientation. Journal for the Scientific Study of Religion, 1, 175-181. http://dx.doi.org/10.2307/1387592

Newberg, A. (2010). Principles of neurotheolgy. New York: Ashgate.

Otto, R. (1968). Le sacre: L'élément non-rationnel dans l'idée du divin et sa relation avec le rationnel. Paris: Payot.

Pafford, M. (1973). Inglorious Wordsworths: A Study of Some Transcendental Experiences in Childhood and Adolescence. London: Hodder and Stoughton.

Pahnke, W. (1966). Drugs and Mysticism. International Journal of Parapsychology, 8, 295-314.

Pargament, K., \& Mahoney, A. (2005). Sacred matters: Sanctification as a vital topic for the psychology of religion. The International Journal for the Psychology of Religion, 3, 179-198. http://dx.doi.org/10.1207/s15327582ijpr1503_1

Peteet, J. (1981). Issues in the Tratement of Religious Patients. American Journal of Psychotheraphy, 35, 559-564.

Poloma, M., \& Gallup, G. (1991). Varieties of Prayer: A Survey Report. Philadelphia: Trinity Press International.

Popielski, K. (1987). Testy egzystencjalne: Metody badania frustracji egzystencjalnej i nerwicy noogennej. W: Popielski, K. (red.). Człowiek - pytanie otwarte (Existential Tests: Tests of Existential Frustration and Neurosis Noogennej). In K. Popielski (ed.), Man - the Question Open (pp. 237-261). Lublin: Red. Wyd. KUL.

Popielski, K. (2008). Psychologia egzystencji (Psychology of Existence). Lublin: KUL.

Rahner, K. (1984). Corso fundamentale sulla fede. Introduzione al concetto di cristianesimo. Torino: Ed. Paoline.

Richards, S., \& Bergin, A. (2004). A Theistic Spiritual Strategy for Psychotherapy. In S. Richards, \& A. Bergin (ed.), Casebook for a Spiritual Strategy in Counseling and Psychotherapy (pp. 3-32). Washington, DC: APA. http://dx.doi.org/10.1037/10652-000 
Rogers, C. (1983). Un modo di essere. Firenze: Psycho-di Martinelli.

Saroglou, V. (2002). Religion and the Fave Factors of Personality: A Meta-Analytic Review. $\begin{array}{llll}\text { Personality and Individual Differences, } & 32,\end{array}$ http://dx.doi.org/10.1016/S0191-8869(00)00233-6

Smith, H. (1964). Do Drugs Have Religious Import? Journal of Philosophy, 61, 517-530. http://dx.doi.org/10.2307/2023494

Snyder, S. (1986). Drugs and the Brain. New York: Scientific American Books.

Soiński, B. (2006). Doświadczenia religijne a postawy studentów w obliczu śmierci Jana Pawta II (Religious Experiences and Stiudents Attitudes in the Wake of John Paul II's Death). Poznań: UAM.

Soiński, B. (2010). Osobowość a nawrócenie (The personality and the conversion). Poznań: UAM.

Stevens, J. (1987). Storming Heaven: LSD and the American Dream. New York: Harper and Row.

Szymołon, J. (1999). Lęk i fascynacja (Fear and Fascination). Lublin: KUL.

Vergote, A. (1967). Psicologia religiosa. Torino: Borla Editore.

Wulff, D. (1997). The Psychology of Religion. Classic and Contemporary. New York. Johin Wiley \& Sons.

Zawadzki, B., Strelau, J., Sczczepaniak, P., \& Śliwińska, M. (1998). Inwentarz osobowości NEO-FFI Costy i McCrae (The Personality Inventory). Warszawa: PTP.

Zdybicka, Z. (1979). Les voies de l'affirmation de Dieu. Collectanea Theologica, 49, 77-123.

\section{Copyright Disclaimer}

Copyright reserved by the author(s).

This article is an open-access article distributed under the terms and conditions of the Creative Commons Attribution license (http://creativecommons.org/licenses/by/3.0/). 